\title{
Aeromonas salmonicida isolated from wild and farmed fish and invertebrates in Oman
}

\author{
Aliya Alghabshi $(\mathbb{D} \cdot$ Brian Austin $\cdot$ Margaret Crumlish
}

Received: 6 November 2017/Accepted: 14 May 2018/Published online: 1 June 2018

(C) The Author(s) 2018

\begin{abstract}
Aeromonas salmonicida was isolated from red spot emperor, king soldier bream, white-spotted rabbit fish and tilapia, and an invertebrate (abalone) in Oman during December 2011-May 2012. The cytotoxic enterotoxin ast gene was found widely distributed among the isolates; aerolysin-like protein $(a c t)$ and the flagellin structural gene lafA less so; and the nuclease gene (nис) not at all. However, there was not any evidence of pathogenicity among the isolates when tested in laboratory-based experiments using rainbow trout and Nile tilapia. Therefore, the risk of the pathogen to fish in Oman is unclear.
\end{abstract}

Keywords Aeromonas salmonicida $\cdot$ Fish $\cdot$ Invertebrates $\cdot$ Aquaculture $\cdot$ Oman

\section{Introduction}

Aeromonas salmonicida is the aetiological agent of furunculosis in salmonids and causes ulcer disease in cyprinids and marine flatfish (Austin and Austin 2016). Traditionally, the organism is regarded as an obligate fish pathogen (Schubert 1974) being only recoverable from clinically diseased fish. In part, the restricted ecology reflected the difficulty of recovering viable and culturable cells from fish in the absence of clinical disease or from environmental samples (Austin and Austin 2016). Pathogenesis of Aeromonas infections may be correlated with stress of the susceptible fish and the production of cell-associated and extracellular virulence determinants (Austin and Austin 2016). Although numerous virulence factors, such as surface polysaccharides (capsule, lipopolysaccharide, and glucan), iron-binding systems, exotoxins and extracellular enzymes, secretion systems, fimbriae and flagella, contribute to pathogenesis of fish and human diseases caused by Aeromonas spp., none of the factors alone are responsible for all of the clinical signs of disease presented during an infection (Ali et al. 1996). Variations in the distribution of potential virulence genes between Aeromonas isolates may well contribute to their degree of pathogenicity (Albert et al. 2000). Sha et al. (2002) reported the presence and expression of three enterotoxin genes (alt, ast and act genes) in Aeromonas spp. that led to a $100 \%$ reduction in fluid secretion in a mouse model. Conversely, Sen and Rodgers (2004) reported that the mere presence of these toxins may not be sufficient for virulence. Therefore,

\footnotetext{
A. Alghabshi ( $\square)$

Microbiology Section, Fish Quality Control Centre, Ministry of Agriculture and Fisheries Wealth, Muscat, Sultanate of Oman

e-mail: aliya.7744@gmail.com

B. Austin · M. Crumlish

Institute of Aquaculture, University of Stirling, Stirling, UK
} 
there is a need to continuously assess the presence of several accepted virulence factors in Aeromonas isolates for better understanding of the overall pathogenesis of infections (Sen and Rodgers 2004). The present study was undertaken to investigate the pathogenicity of strains of $A$. salmonicida recovered from a range of aquatic animals in Oman.

\section{Materials and methods}

\section{Bacterial isolates}

In this study, 9 isolates of $A$. salmonicida were recovered from skin, gill and kidney of 417 fish representing 4 wild fish, including red spot emperor (Lethrinus lentjan), king soldier bream (Argyrops spinifer), white-spotted rabbit fish (Siganus canaliculatus), abalone (Haliotis mariae) and one farmed tilapia (Oreochromis niloticus). The fish were collected from 3 areas (Muscat, Mudhaibi and Salalah) considered suitable for aquaculture in Oman based on the Atlas of suitable sites for aquaculture in Oman. The animals were mostly healthy, as judged visually, except for one tilapia that demonstrated abnormal behaviour. The abalone was from a population that had a history of high mortality albeit without any clinical signs of disease.

From freshly dead fish and muscle from the abalone, samples were taken by means of inoculating loops from skin, gill and kidney, and were directly streaked onto the surface of tryptone soya agar plates (TSA; CM0131, Oxoid) with incubation at $28^{\circ} \mathrm{C}$ for $48 \mathrm{~h}$. From each plate with dense growth, colonies representing the most commonly occurring morphological types were aseptically selected and subcultured for purity. Smears were prepared for the Gram-staining reaction and micro-morphology. Catalase production and the determination of motility followed the methods of Frerichs and Millar (1993) and Martin-Carnahan and Joseph (2005), respectively. Oxidase production was determined using oxidase strips (OxiStrips ${ }^{\mathrm{TM}}$, Oxoid). The API 20E rapid identification system (BioMérieux, France) was used following the manufacturer's instructions, except that the inoculated strips were incubated at $28{ }^{\circ} \mathrm{C}$ and the results read at $48 \mathrm{~h}$ (Crumlish et al. 2002). The demonstration of haemolysin activity was assessed from the presence of complete ( $\beta$ haemolysis) or incomplete ( $\alpha$-haemolysin) zones of clearing around colonies on 5\% sheep blood agar following incubation at $28{ }^{\circ} \mathrm{C}$ for $48 \mathrm{~h}$. The susceptibility to the vibriostatic agent $(\mathrm{O} / 129)(150$ - and 10- $\mu \mathrm{g}$ discs; Oxoid) was achieved by the disc method of Kirby and Bauer on TSA agar plates (Buller 2004). After 24-h incubation at $28{ }^{\circ} \mathrm{C}$, zones of clearing of $<7$ and $>7 \mathrm{~mm}$ were recorded as indicative of resistance and sensitivity, respectively (Whitman 2004). Serology was determined by indirect agglutination reactions using the MONO-As kit (BIONOR AS, Skien, Norway) for A. salmonicida, following the manufacturer's instructions. This kit consists of antibody-coated latex beads, and is designed for specific identification of all $A$. salmonicida. Growth at $5,20,22,28,30$ and $37{ }^{\circ} \mathrm{C}$ and the ability to produce brown diffusible pigment were evaluated on TSA (Austin et al. 1998). Here, inoculated media were examined every $24 \mathrm{~h}$ for up to 5 days to determine the presence of colony growth, and up to 14 days to assess for brown diffusible pigment production. For each test performed, a positive control, i.e. A. salmonicida subsp. salmonicida (NCIMB $1102^{\mathrm{T}}$ ), was included.

Molecular identification

Genotyping of the suspected A. salmonicida used 16S rRNA sequencing (Borrell et al. 1997) and rDNA-RFLP (Borrell et al. 1997; Figueras et al. 2000). Species identification was confirmed by comparing the DNA sequence obtained in this study with the NCBI GenBank database using BLAST [basic local alignment search tool, standard nucleotide comparison (http://www.ncbi.nlm.nih.gov/BLAST/)] (Altschul et al. 1990). The sequences were aligned using ClustalW for multiple sequence alignment with the DNASTAR computer program and phylogenetic analyses (maximum likelihood method) were conducted by the MEGA software version 6.0 (Tamura et al. 2013) to provide a phylogenetic tree. Standard errors were obtained with 1000 bootstrap replicates. 
Preparation of extracellular products (ECP)

ECP was prepared using the cellophane overlay method of Gudmundsdóttir (1996). The bacteria were grown in tryptone soya broth (TSB; Oxoid) for $24 \mathrm{~h}$ at $28{ }^{\circ} \mathrm{C}$, and centrifuged at $10,000 \times g$ at $4{ }^{\circ} \mathrm{C}$ for $30 \mathrm{~min}$. The supernatant containing the ECP fractions was sterilized by filtration through $0.22-\mu \mathrm{m}$ filters (Millipore). To confirm the absence of bacterial colonies, $0.2 \mathrm{ml}$ volume of the filtered supernatants was streaked over TSA plates and incubated for $48 \mathrm{~h}$ at $28{ }^{\circ} \mathrm{C}$. The protein concentration of the ECP was determined by the method of Bradford (1976) using a protein determination kit (Bio-Rad, USA) according to the manufacturer's instructions with bovine serum albumin (BSA; Sigma-Aldrich, UK) as the standard. The ECP extractions were then subsequently stored at $-20{ }^{\circ} \mathrm{C}$ until required.

Determination of putative virulence characteristics

Bacteria from 24-h-old cultures on TSA and filtered supernatants obtained from the ECP preparations were used to assess protease activity (Gudmundsdóttir 1996), haemolytic activity (Brender and Janda 1987), DNase activity (Buller 2004), Congo red dye uptake (Crump and Kay 2008) and the production of A-layer as visualized on Coomassie brilliant blue agar (CBB; Cipriano and Bertolini 1988). Positivity for A-layer was indicated by the presence of dark-red colonies on Congo red agar and dark-blue colonies on CBB agar, whereas negativity was indicated by the presence of pale colonies on these media.

Detection of virulence genes

The presence of genes encoding the virulence factors aerolysin (aer) (Pollard et al. 1990), aerolysin-like proteins (act) (Sen and Rodgers 2004), cytotoxic enterotoxins (ast, alt) (Aguilera-Arreola et al. 2005), glycerophospholipid cholesterol acyltransferase (gcat) (In-Young and Kiseong 2007), structural gene flagellin (lafA, lafB) (Aguilera-Arreola et al. 2005) (In-Young and Kiseong 2007) and serine protease (In-Young and Kiseong 2007) was determined by use of the polymerase chain reaction (PCR) using primers and conditions already published.

Determination of pathogenicity

Cells from 24-h cultures in TSB were harvested by centrifugation, washed in $0.85 \%(\mathrm{w} / \mathrm{v})$ saline and the optical density $\left(\mathrm{OD}_{600}\right)$ was adjusted to 1 . Viable colony counts were performed following the Miles and Misra (1938) method and tenfold serial dilutions prepared for challenge studies in tilapia and rainbow trout. The first challenge was performed in the Fishery Quality Control Centre in Oman using farmed tilapia stocks of $30 \mathrm{~g}$ average weight. The fish were fed with commercial pelleted fish diet for the 5-day period of each experiment with quarantine for 14 days prior to administration of $0.1 \mathrm{ml}$ volume of bacterial suspension containing $10^{8}$ cells fish ${ }^{-1}$ by intraperitoneal (i.p) and intramuscular (i.m) injections. Control fish received $0.1 \mathrm{ml}$ volume of sterile $0.85 \%$ (w/v) saline by i.p. and i.m. injections. A second experiment was performed at the University of Stirling using the same concentration of bacterial cells in an in-house tilapia population of $30 \mathrm{~g}$ average weight and farmed rainbow trout of $50 \mathrm{~g}$ average weight. The fish at Stirling were health checked prior to use, where tissue samples were aseptically taken from a subsamples of the group and fixed in $10 \%$ neutral buffered formalin before processing into wax-embedded tissue sections. These were trimmed and $5-\mu \mathrm{m}$ sections cut, stained with haemotoxylin and eosin and viewed for health check prior to any experimentation. Additional fish experiments sought to determine the effect of ECPs, which were injected i.m. and i.p. in $0.1 \mathrm{ml}$ volume $\left(0.1 \mathrm{mg}\right.$ of protein $\left.\mathrm{ml}^{-1}\right)$. Control fish received $0.1 \mathrm{ml}$ volume of sterile $0.85 \%(\mathrm{w} / \mathrm{v})$ saline. All fish were maintained in freshwater at $26 \pm 2$ and $15 \pm 1{ }^{\circ} \mathrm{C}$ for tilapia and rainbow trout, respectively, and examined daily for 5 days. Any dead or clinically diseased fish were sampled microbiologically in which loopfuls of samples from kidney and spleen were streaked onto TSA plates with incubation at $28{ }^{\circ} \mathrm{C}$ for $24 \mathrm{~h}$, and the resulting colonies identified as previously described. Also, spleen and kidney tissues were fixed in $10 \%(\mathrm{v} / \mathrm{v})$ neutral buffered formalin for $24 \mathrm{~h}$ before embedding in paraffin following routine tissue processing. Thus, $5-\mu \mathrm{m}$-thick sections were cut and stained with haematoxylin and eosin (H\&E) (Oliveira Ribeiro et al. 1981) and Gram stained for histological examination. All slides were examined at a magnification of $400 \times$ using a Carl Zeiss microscope. 


\section{Results and discussion}

Nine isolates of A. salmonicida were recovered and identified from skin, gill and kidney from four fish species, i.e. red spot emperor, king soldier bream, white-spotted rabbit fish, tilapia and one of abalone, all of which are considered as commercially important for aquaculture development in Oman.

These isolates were all tentatively equated with A. salmonicida (Martin-Carnahan and Joseph 2005), insofar as they produced smooth convex colonies on TSA, and comprised Gram-negative rod-shaped bacteria that grew at $5-30{ }^{\circ} \mathrm{C}$, produced catalase, $\beta$-galactosidase, gelatinase, indole and oxidase, but not tryptophan deaminase or urease, fermented glucose, mannose, rhamnose, melibiose and sucrose but not inositol, they did not utilize sodium citrate and were positive for the Voges-Proskauer reaction. All biochemical test results using the API 20E rapid identification kit were in agreement with those of the NCIMB reference strain (Table 1). Unlike descriptions of virulent $A$. salmonicida subsp. salmonicida as recovered from furunculosis in salmonids (McCarthy and Roberts 1980), the Omani strains did not produce brown diffusible pigment around the colonies on TSA, and so the isolates correspond to the description of 'atypical' A. salmonicida (Austin et al. 1998; Martin-Carnahan and Joseph 2005). Sequencing of the 16S rRNA gene revealed that three isolates, 291MS, 293MS and 295MS, had the highest (99\%) similarity with A. salmonicida spp., sequences deposited in GenBank, whereas isolates 373MG and 388MS demonstrated 98\% homology, and 395M, 340M, $26 \mathrm{MS} 2$ and 16MG revealed 95-92\% identity levels, respectively (Fig. 1). It is emphasized that reliance only on sequence analysis of the $16 \mathrm{~S}$ rRNA gene to identify A. salmonicida has limited value, although the technique is useful for confirmation of membership of the genus Aeromonas (Figueras et al. 2011; Han et al. 2011).

Extracellular nuclease and haemolysin activities are considered to be virulence-associated factors belonging to many Aeromonas species (González-Rodríguez et al. 2002; Rahman et al. 2002). Haemolytic activity was present in $67 \%$ of the isolates, whereas extracellular protease occurred in $44 \%$ of the cultures from Oman. Only a minority of the isolates demonstrated uptake of Congo red (22\%) and CBB (33\%).

Table 1 Differential phenotypic characteristics of the isolates

\begin{tabular}{|c|c|c|c|c|c|c|c|c|c|c|}
\hline \multirow[t]{2}{*}{ Phenotypic characteristics } & \multicolumn{10}{|l|}{ Isolate no. } \\
\hline & $\begin{array}{l}\text { A. } \\
\text { salmonicida }^{\mathrm{a}}\end{array}$ & $16 \mathrm{MG}$ & 26MS2 & 291MS & 293MS & 295MS & $340 \mathrm{M}$ & $373 \mathrm{MG}$ & $388 \mathrm{MS}$ & $395 \mathrm{M}$ \\
\hline Colonial colour on TSA & $\mathrm{N}$ & B & B & B & B & B & A & B & B & B \\
\hline Motility & $\mathrm{V}$ & - & + & + & + & + & - & + & + & + \\
\hline Pigment production & $\mathrm{V}$ & - & - & - & - & - & - & - & - & - \\
\hline Autoagglutination in saline & V & - & - & + & - & - & - & - & - & - \\
\hline \multicolumn{11}{|l|}{ Growth at: } \\
\hline $5^{\circ} \mathrm{C}$ & V & - & - & + & + & + & - & - & + & - \\
\hline $37^{\circ} \mathrm{C}$ & V & + & + & + & + & + & + & + & + & + \\
\hline Arginine dihydrolase & $\mathrm{V}$ & + & + & + & + & + & + & + & + & + \\
\hline Lysine decarboxylase & $\mathrm{V}$ & + & + & + & - & - & + & + & + & + \\
\hline Ornithine decarboxylase & $\mathrm{V}$ & - & + & - & - & - & - & + & - & - \\
\hline $\mathrm{H}_{2} \mathrm{~S}$ production & $\mathrm{V}$ & - & - & - & - & - & - & - & - & - \\
\hline Fermentation of sorbitol & $\mathrm{V}$ & + & - & + & - & - & + & + & -- & - \\
\hline Fermentation of rhamnose & - & + & - & - & - & - & + & - & - & - \\
\hline Fermentation of melibiose & - & + & - & - & - & - & + & - & - & - \\
\hline Fermentation of amygdalin & V & + & - & + & + & - & + & + & + & + \\
\hline Fermentation of arabinose & V & + & - & + & + & + & + & + & - & - \\
\hline $\begin{array}{l}\text { Susceptibility to the } \\
\text { vibriostatic agent } \\
\text { O/129:150 } \mu \mathrm{g} / 10 \mu \mathrm{g}\end{array}$ & $\mathrm{R} / \mathrm{R}$ & $\mathrm{R} / \mathrm{R}$ & $\mathrm{S} / \mathrm{S}$ & $\mathrm{R} / \mathrm{R}$ & $\mathrm{R} / \mathrm{R}$ & $\mathrm{R} / \mathrm{R}$ & $\mathrm{S} / \mathrm{R}$ & $\mathrm{S} / \mathrm{R}$ & $\mathrm{S} / \mathrm{S}$ & $\mathrm{R} / \mathrm{R}$ \\
\hline
\end{tabular}

A, light creamy colonies; B, yellowish colonies; +, positive; -, negative; V, variable result; N, no data; R, resistant; S, sensitive ${ }^{a}$ Data are from the following references: Abbott et al. (1992), Austin et al. (1989), Carnahan and Altwegg (1996), Huys et al. (1996), Griffiths et al. (1953), Schubert (1974), McCarthy and Roberts (1980), Pavan et al. (2000) and Yamada et al. (2000) 


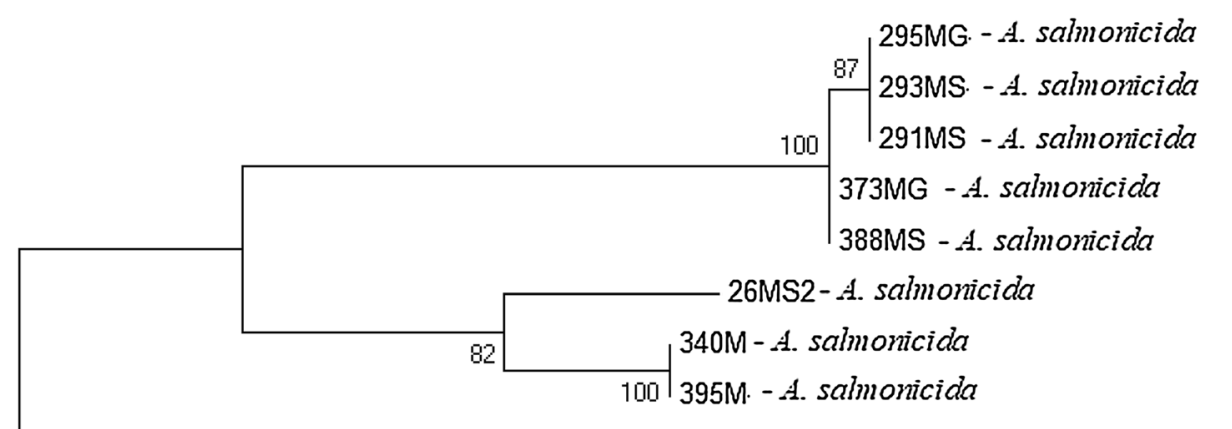

$16 \mathrm{MG}$ - A. salmonicida

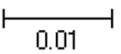

Fig. 1 The phylogenetic tree based on 16S rRNA fragment sequences, showing relationship of the A. salmonicida cultures (constructed by maximum likelihood method using MEGA6 software); scale bar 0.01 represents sequence divergence

Haemolytic and proteolytic activities were not seen in any of the ECPs. The distribution of the putative virulence genes has been presented in Table 2. Thus, the ast gene was distributed among $67 \%$ of the isolates; slightly less (56\%) contained aerolysin-like proteins (act). The genes for lafA (33\% of isolates) were less common. Also, aerA, alt, gcat and ser were present in only $22 \%$ of the cultures, lafB occurred in a single isolate; and nис not at all.

In this study, mortalities were not recorded in any of the challenge experiments. Indeed, pathological changes were not observed in any of the tissues examined by histology (Fig. 2), although i.p. injection of isolate $340 \mathrm{M}$ in rainbow trout led to the development of pale liver and darkened kidneys. Moreover, only fish injected with $16 \mathrm{MG}$ and $340 \mathrm{M}$ contained culturable cells at the end of the experiments.

The discrepancy in the presence of aerolysin (aerA) and aerolysin-like protein (act) genes among the Omani cultures suggested that the isolates may possess but not express these genes (Wang et al. 2003) under the situations described. Enterotoxin genes alt, ast and act were not expressed in any of the isolates. Two cultures harboured both act and ast genes, which is unusual as this combination has been only rarely reported among environmental isolates (Albert et al. 2000; Chang et al. 2008). Yet, pathogenicity was not recorded among these isolates. Some studies reported a correlation between the higher number of virulence genes harboured in Aeromonas spp. and their potential for causing disease (Albert et al. 2000; Chang et al. 2008). These workers mentioned that the number of isolates positive for both the alt and ast genes was significantly higher in children with diarrhoea than for healthy controls. In this study, there was not any such correlation. An explanation could be that the experimental conditions used in this study influenced the expression of the genes involved in pathogenicity. Also, the level of virulence has inevitably been correlated with the amount of enzymes and toxins produced (Kozińska 1996). Another possibility is that their presence in A. salmonicida does not infer that disease is inevitable reflecting the susceptibility of the host, immune state and actual number of bacterial cells in and around the host (Ottaviani et al. 2011). Notwithstanding, some isolates did lead to the development of small haemorrhages in/on the internal organs, as reported previously (Austin and Adams 1996). In this respect, it is worthwhile to consider the comments of Austin and Austin (1993) and Austin (2011), who considered that loss of virulence might well reflect the effects of storage, i.e. the transition to what are effectively laboratory cultures, and the inability to replicate conditions of the initial disease, which led to the recovery of the cultures.

The recovery of A. salmonicida from Omani fish and abalone in the absence of clinical signs of disease contradicts the commonly held view that the organism is an obligate fish pathogen. However, this may reflect that scientists have focused on recovery only from diseased fish, namely salmonids, cyprinids and marine flatfish, rather than other groups of aquatic animals and environmental samples. All the isolates recovered in this study had similar morphologies and lacked diffusible brown pigment production. Also, there was not any direct relationship found between pathogenicity and the presence of putative virulence factors. Again, it is questionable whether this reflects the loss of activity during storage. Clearly, further research is needed to extend the knowledge of this group of organisms, particularly in an emerging aquaculture industry. 


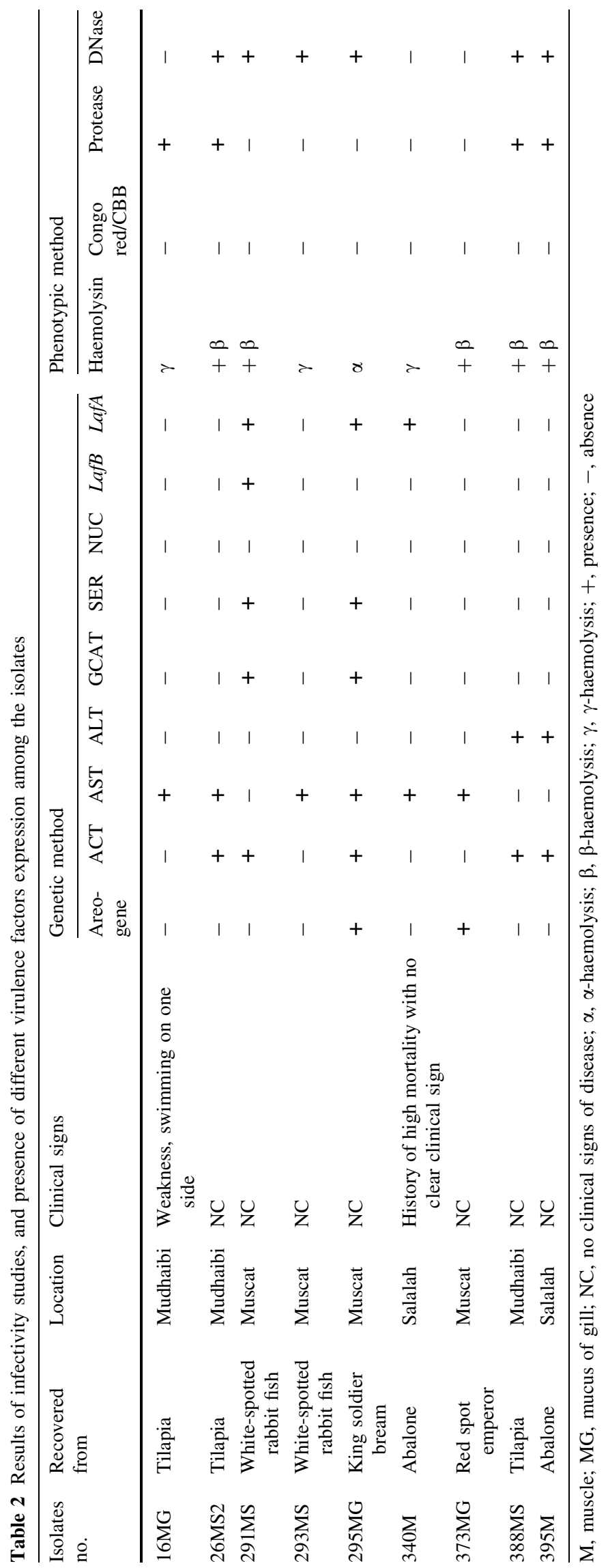



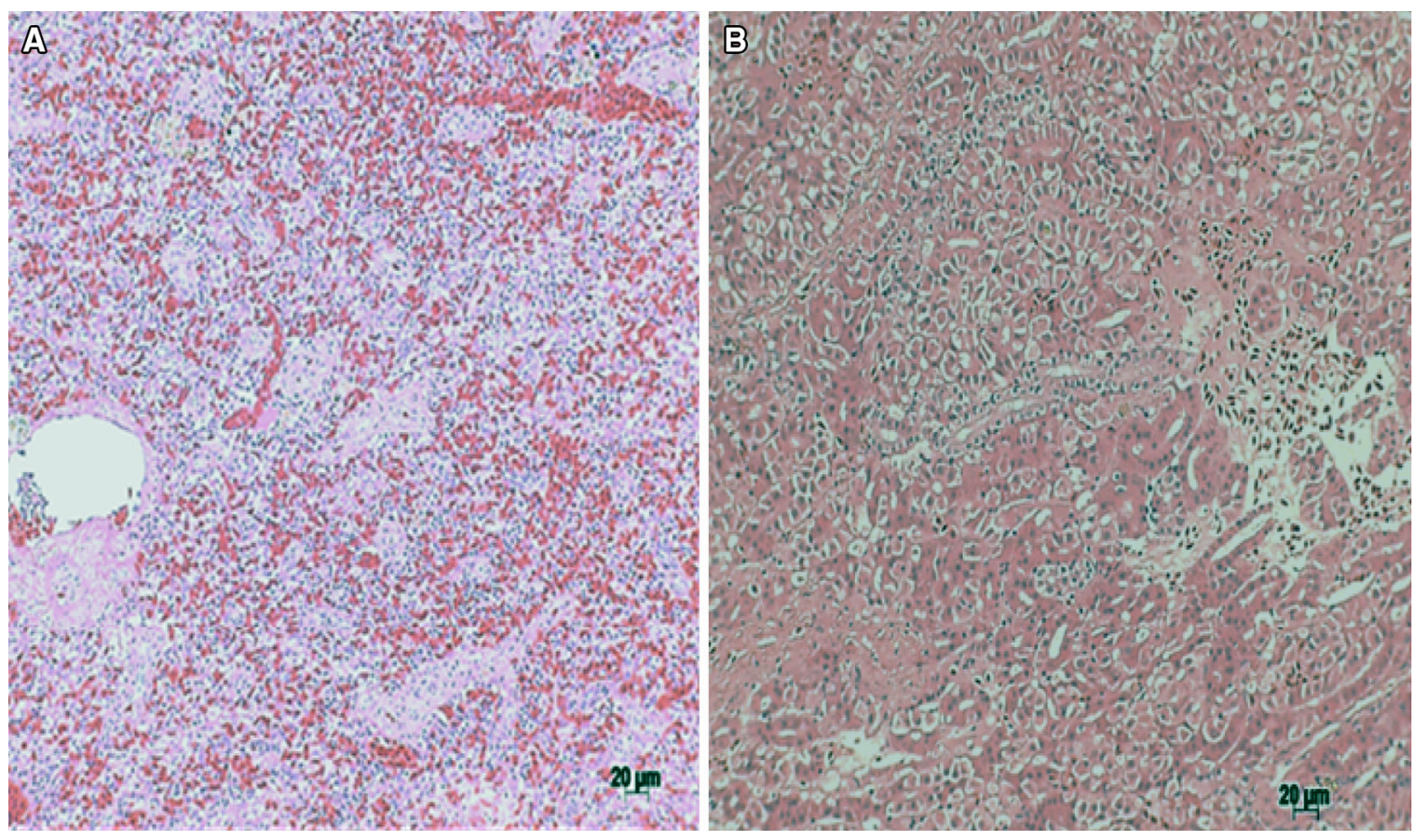

Fig. 2 Light microscopic appearance of the (a) spleen and (b) kidney of tilapia injected with extracellular products (ECP) of $A$. salmonicida isolates (H\&E, scale bar $20 \mu \mathrm{m}$ )

Acknowledgements The authors acknowledge financial support from the Agricultural and Fishery Development Fund-1/3/30) AFDF), Sultanate of Oman.

\section{Compliance with ethical standards}

Conflict of interest The authors declare that there is no conflict of interest.

Open Access This article is distributed under the terms of the Creative Commons Attribution 4.0 International License (http:// creativecommons.org/licenses/by/4.0/), which permits unrestricted use, distribution, and reproduction in any medium, provided you give appropriate credit to the original author(s) and the source, provide a link to the Creative Commons license, and indicate if changes were made.

\section{References}

Abbott S, Cheung WK, Kroske-Bystrom S, Malekzadeh T, Janda JM (1992) Identification of Aeromonas strains to the genomospecies level in the clinical laboratory. J Clin Microbiol 30:1262-1266

Aguilera-Arreola MC, Hernández-Rodríguez C, Zúñiga G, Figueras M, Castro-Escarpulli G (2005) Aeromonas hydrophila clinical and environmental ecotypes as revealed by genetic diversity and virulence genes. FEMS Microbiol Lett 242:231-240

Albert M, Ansaruzzaman M, Talukder K, Chopra A, Kuhn I, Rahman M, Islam MS (2000) Prevalence of enterotoxin genes in Aeromonas spp. isolated from children with diarrhea, healthy controls, and the environment. J Clin Microbiol 38:3785-3790

Ali A, Carnahan A, Altwegg M, Lütthyhottenstein J, Joseph S (1996) Aeromonas bestiarum sp. nov. (formerly genomospecies DNA group 2 A. hydrophila), a new species isolated from non-human sources. Med Microbiol Lett 5:156-165

Altschul S, Gish W, Miller W, Myers E, Lipman D (1990) Basic local alignment search tool. J Mol Biol 215:403-410

Austin B (2011) Taxonomy of bacterial fish pathogens. Vet Res 42(1):20. https://doi.org/10.1186/1297-9716-42-20

Austin B, Adams C (1996) Fish pathogens. In: Austin B, Altwegg M, Gosling PJ, Joseph S (eds) The genus Aeromonas. Wiley, Chichester, pp 198-243

Austin B, Austin D (1993) Aeromonadaceae representatives Aeromonas salmonicida. In: Austin B, Austin DA (eds) Bacterial fish diseases: disease in farmed and wild fish. Ellis Horwood, Chichester, pp 86-170

Austin B, Austin DA (2016) Bacterial fish pathogens: disease of farmed and wild fish, 6th edn. Springer, Dordrecht

Austin DA, Mclntosh D, Austin B (1989) Taxonomy of fish associated Aeromonas spp., with the description of Aeromonas salmonicida subsp. smithia subsp. nov. Syst Appl Microbiol 11:277-290

Austin B, Austin DA, Dalsgaard I, Gudmundsdóttir B, Hoie S, Thornton J, Powell B (1998) Characterization of atypical Aeromonas salmonicida by different methods. Syst Appl Microbiol 21:50-64

Borrell N, Acinas G, Figueras M, Martinez-Murcia A (1997) Identification of Aeromonas clinical isolates by restriction fragment length polymorphism of PCR-amplified 16S rRNA genes. J Clin Microbiol 35:1671-1674

Bradford M (1976) Bio-rad protein assay. Anal Biochem 72:248 
Brender R, Janda JM (1987) Detection, quantitation and stability of the beta haemolysin of Aeromonas spp. J Clin Microbiol 24(3):247-251

Buller NB (2004) Bacteria from fish and other aquatic animals. A practical identification manual. CABI, Wallingford

Carnahan A, Altwegg M (1996) Taxonomy. In: Austin B, Altwegg M, Gosling PJ, Joseph S (eds) The genus Aeromonas. Wiley, Chichester, pp 1-38

Chang Y, Wang J, Selvam A, Kao S, Yang SS, Shih DYC (2008) Multiplex PCR detection of enterotoxin genes in Aeromonas spp. from suspect food samples in Northern Taiwan. J Fd Protect 71:2094-2099

Cipriano RC, Bertolini (1988) Selection for virulence in the fish pathogen Aeromonas salmonicida, using Coomassie Brilliant Blue agar. J Wildl Dis 24(4):672-678

Crumlish M, Dung TT, Turnbull JF, Ngoc NTN, Ferguson HW (2002) Identification of Edwardsiella ictaluri from diseased freshwater catfish, Pangasius hypophthalmus (Sauvage), cultured in the Mekong Delta, Vietnam. J Fish Dis 25:733-736

Crump EM, Kay WW (2008) Congo red inhibition as a convenient diagnostic for Flavobacterium psychrophilum. J Fish Dis 31:553-557

Figueras M, Guarro J, Martínez-Murcia A (2000) Use of restriction fragment length polymorphism of the PCR-amplified 16S rRNA gene for the identification of Aeromonas spp. J Clin Microbiol 38:2023-2025

Figueras M, Beaz-Hidalgo R, Collado L, Martinez-Murcia AJ (2011) Point of view on the recommendations for new bacterial species description and their impact on the genus Aeromonas and Arcobacter. Bull Bergey's Int Soc Microb Syst 2:1-16

Frerichs GN, Millar SD (1993) Manual for the isolation and identification of fish bacterial pathogens. Pisces Press, Stirling

González-Rodríguez MN, Santos A, Otero JA, García-López ML (2002) PCR detection of potentially pathogenic aeromonads in raw and cold-smoked freshwater fish. J Appl Microbiol 93:675-680

Griffiths PJ, Snieszko SF, Friddle S (1953) A more comprehensive description of Bacterium salmonicida. Trans Am Fish Soc 82:129-138

Gudmundsdóttir B (1996) Comparison of extracellular proteases produced by Aeromonas salmonicida strains, isolated from various fish species. J Appl Bacteriol 80:105-113

Han H, Kim D, Kim W, Kim C, Jung S, Oh M, Ki DH (2011) Atypical Aeromonas salmonicida infection in the black rockfish, Sebastes schlegeli Hilgendorf, in Korea. J Fish Dis 34:47-55

Huys G, Coopman R, Janssen P, Kersters K (1996) High-resolution genotypic analysis of the genus Aeromonas by AFLP fingerprinting. Int J Syst Bacteriol 46:572-580

In-Young N, Kiseong J (2007) Rapid detection of virulence factors of Aeromonas isolated from a trout farm by hexaplex-PCR. J Microbiol (Seoul, Korea) 45:297-304

Kozińska A (1996) Wskazniki patogennosci Aeromonas hydrophila, Aeromonas caviae, Aeromonas sobria. Praca doktorska. Puławy: Pan' stwowy Instytut Weterynaryjny

Martin-Carnahan A, Joseph S (2005) Genus I. Aeromonas Stanier 1943, 213 ${ }^{\text {AL }}$. In: Brenner DJ, Krieg NR, Staley JT, Garrity GM (eds) Bergey's manual of systematic bacteriology, vol 2, part B, 2nd edn. Springer, New York

McCarthy DH, Roberts RJ (1980) Furunculosis of fish - the present state of our knowledge. In: Droop MR, McCarthy DH, Jannasch HW (eds) Advances in aquatic microbiology. Academic Press, London

Miles A, Misra S (1938) The estimation of the bactericidal power of the blood. J Hyg (Lond) 38:732-749

Oliveira Ribeiro CA, Vollaire Y, Sanchezchardi A, Roche H (1981) Bioaccumulation and the effects of organochlorine pesticides, PAH and heavy metals in the Eel (Anguilla anguilla) at the Camargue Nature Reserve, France. Aquat Toxicol 74:53-69

Ottaviani D, Parlani C, Citterio B, Masini L, Leoni F, Canonico C, Pianetti A (2011) Putative virulence properties of Aeromonas strains isolated from food environmental and clinical sources in Italy: a comparative study. Int J Fd Microbiol 144:538-545

Pavan ME, Abbott SL, Zorzo J, Janda JM (2000) Aeromonas salmonicida subsp. pectinolytica subsp. nov., a new pectinasepositive subspecies isolated from a heavily polluted. Int J Syst Evol Microbiol 50:1119-1124

Pollard DR, Johnson WM, Lior H, Tyler SD, Rozee KR (1990) Detection of the aerolysin gene in Aeromonas hydrophila by the polymerase chain reaction. J Clin Microbiol 28:2477-2481

Rahman M, Colque-Navarro P, Kuhn I, Ugent GH, Ugent JS, Mollby R (2002) Identification and characterization of pathogenic Aeromonas veronii biovar sobria associated with epizootic ulcerative syndrome in fish in Bangladesh. Appl Environ Microbiol 68:650-655

Schubert RH (1974) Genus II. Aeromonas Kluyver and van Niel 1936, 398. In: Buchanan RE, Gibbons NE (eds) Bergey's manual of determinative bacteriology, 8th edn. Williams and Wilkins, Baltimore

Sen K, Rodgers M (2004) Distribution of six virulence factors in Aeromonas species isolated from US drinking water utilities: a PCR identification. J Appl Microbiol 97:1077-1086

Sha J, Kozlova E, Chopra A (2002) Role of the various enterotoxins in Aeromonas hydrophila-induced gastroenteritis: generation of enterotoxin gene-deficient mutants and evaluation of their enterotoxic activity. Infect Immun 70:1924-1935

Tamura K, Stecher G, Peterson D, Filipski A, Kumar S (2013) MEGA6: molecular evolutionary genetics analysis version 6.0. Mol Biol Evol 30:2725-2729

Wang G, Clark CG, Liu C, Pucknell C, Munro CK, Kruk TMA, Rodgers G (2003) Detection and characterization of the hemolysin genes in Aeromonas hydrophila and Aeromonas sobria by multiplex PCR. J Clin Microbiol 41:1048-1054

Whitman K (2004) Finfish and shellfish bacteriology. Manual; techniques and procedures. Iowa State Press, Iowa, p 258

Yamada Y, Kaku Y, Wakabayashi H (2000) Phylogenetic intrarelationships of atypical Aeromonas salmonicida isolated in Japan as determined 16S rDNA sequencing. Fish Pathol 35:35-40

\section{Publisher's Note}

Springer Nature remains neutral with regard to jurisdictional claims in published maps and institutional affiliations. 